\title{
Diagenetic alterations of amino acids and organic matter in the upper Pearl River Estuary surface sediments
}

\section{J. Zhang, R. Zhang, Q. Wu, and N. Xu}

School of Environmental Science and Engineering, Sun Yat-sen University, Guangzhou, Guangdong 510275, China

Correspondence to: Q. Wu (eeswqh@mail.sysu.edu.cn)

Received: 11 March 2011 - Published in Biogeosciences Discuss.: 29 March 2011

Revised: 19 December 2011 - Accepted: 6 January 2012 - Published: 27 January 2012

\begin{abstract}
The objective of this study was to investigate the diagenetic alteration of sediment organic matter (OM) in the upper Pearl River Estuary. Sediment analyses were conducted for three size fractions of OM, including coarse particulate OM (CPOM), fine particulate OM (FPOM), and ultrafiltered dissolved OM (UDOM). Results showed that the highest and lowest carbon $(\mathrm{C})$ : nitrogen $(\mathrm{N})$ ratios were in CPOM and UDOM, respectively, indicating that CPOM was relatively enriched in organic $\mathrm{C}$. The highest average total $\mathrm{N}$ content in the FPOM fraction showed that FPOM was enriched in N-containing molecules. Our study showed that the "size-reactivity continuum" model was applicable to sediment particulate and dissolved OM. Distributions of amino acids and their D-isomers among the sediment fractions indicated that the amino acid-based diagenetic index, C:N ratio, and percentage of total $\mathrm{N}$ represented by total hydrolysable amino acids could be used as diagenetic indicators. Furthermore, the diagenetic state of sediment OM could also be characterized by $\mathrm{C}$ - and $\mathrm{N}$-normalized yields of total $\mathrm{D}$ amino acids, and $\mathrm{C}$ - and $\mathrm{N}$-normalized yields of $\mathrm{D}$-alanine, D-glutamic acid, and D-serine.
\end{abstract}

\section{Introduction}

Bio-molecules undergo major transformations in the natural environment following the disintegration of bacterial cell materials through death (Tremblay and Benner, 2009), viral lysis (Riemann and Middelboe, 2002), and protist grazing of source organisms (Nagata and Kirchman, 2000). Heterotrophic microorganisms are the primary agent of decomposition, and exhibit a significant impact on preserved organic matter (OM) abundance and biochemical composition (Tremblay and Benner, 2009). Over half of the nonliving (or detrital) $\mathrm{OM}$ in aquatic environments still remains unidentified at the molecular level (Hedges et al., 2000), although extensive effort has been taken to determine its origins, productions, and diagenetic alterations.

Several studies have confirmed the occurrence and origin of bacterial biomarkers in OM from water columns and sediments (Jørgensen and Middelboe, 2006; Lomstein et al., 2006; Lomstein et al., 2009; Pedersen et al., 2001; Tremblay and Benner, 2009). Among these biomarkers are amino acids and the respective D-enantiomers. Amino acid-based parameters have been shown to be useful as source indicators of particulate OM through the comparison of the yields and compositions of amino acids and the associated D-enantiomers between OM samples and source materials (Cowie and Hedges, 1992; Lomstein et al., 2006; Pedersen et al., 2001).

The yields and compositions of total hydrolysable amino acids (THAA) pool have been used successfully as diagenetic indicators because they are selectively decomposed or preferentially preserved during diagenesis, and seem uncompromised to source variations (Amon et al., 2001; Dauwe and Middelburg, 1998; Keil et al., 2000; Vandewiele et al., 2009). Based on microbial decomposition of dissolved OM in a marine water column on a short time scale, Davis et al. (2009) reported that carbon (C)-normalized amino acid yields were the most effective indicator for early dissolved OM diagenesis, relative abundances of amino acid yields for intermediate stages of diagenesis, and the mole percent composition of the non-protein amino acid ( $\gamma$-aminobutyric acid) for advanced diagenesis. Dauwe et al. (1999) revealed systematically compositional changes upon progressive particulate OM degradation and derived a quantitative degradation index based on amino acid compositions of particulate OM samples from various marine environments. Also, the amino acid-based degradation index has been successfully used to characterize the diagenetic status of $\mathrm{OM}$ in marine and coastal sediments (Dauwe and Middelburg, 1998; Lomstein et al., 2006). However, there is little information on the diagenetic alteration and degradation status of $\mathrm{OM}$ with 


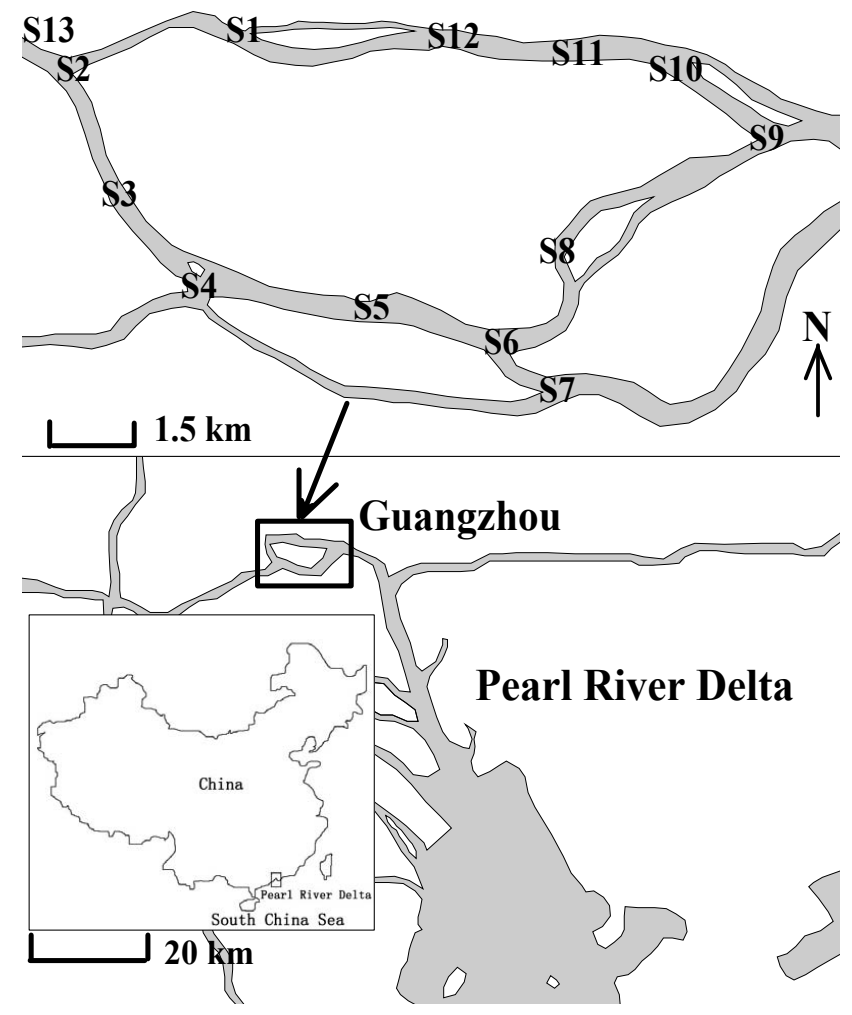

Fig. 1. Sampling stations along the Guangzhou reaches of the Pearl River Estuary, South China: S1 (Ersha Island), S2 (Baietan), S3 (Hedong Bridge), S4 (Yuxi Community), S5 (Luoxi Bridge), S6 (Xiaozhou Village), S7 (Nansha Express), S8 (Luntouhai), S9 (Emei Zhou), S10 (Xinchong Kou), S11 (Linjiang Road), S12 (Liede Village), S13 (Huadi Chong).

different sizes. Amon and Benner (1996) proposed the "sizereactivity continuum" model for aquatic dissolved OM, in which OM reactivity decreases with declining size as diagenetic alteration progresses. Tremblay and Benner (2009) found a consistent trend of increasing proportions of DAAs among Amazon River detrital size fractions in water columns and suggested the portion of DAAs as a useful diagenetic indicator for water column particulate and dissolved OM. Nevertheless, until now no studies are available on the diagenetic state of sediment OM of different sizes, especially in estuarine sediments.

The yield and composition of THAA pool have been used to quantify bacterial contributions to OM (Lomstein et al., 2009). Pedersen et al. (2001) showed that the percentages of four DAAs in the THAA pool increased with the sediment depth and that bacterial peptidoglycan contributed to the pool of organic nitrogen $(\mathrm{N})$. Measuring the DAA composition in THAA, Kaiser and Benner (2008) found that bacterial detritus was the major component of particulate $\mathrm{OM}$ and an important source of submicron size particles and colloids in the ocean water columns. These amino acid-based indicators are affected by many factors, such as sediment depth (Pedersen et al., 2001), diagenetic status (Lomstein et al., 2009), and OM size (Kaiser and Benner, 2008).

Therefore, the aim of this study was to assess the diagenetic status of sediment OM of different size fractions through measurements of compositions and concentrations of sediment particulate and dissolved amino acids. Moreover, the applicability of the "size-reactivity continuum" model in sediments was also investigated.

\section{Materials and methods}

\subsection{Site description}

The Guangzhou reach of the Pearl River Estuary (GZPR) was selected as the study site (Fig. 1). The Pearl River crosses Guangdong Province, China in the subtropical region, and opens to the northern part of the South China Sea (Yin and Harrison, 2008). The GZPR is in the upper Pearl River estuary (PRE). The tidal range at the GZPR is nearly $1.2 \mathrm{~m}$, affected by the Guangdong micro-tidal coast (irregular semidiurnal tide) and the inverted funnel-shape topography of the PRE (Harrison et al., 2008). The GZPR is quite shallow with an average water depth less than $10 \mathrm{~m}$. The fresh water from the GZPR discharges into the PRE and adjacent South China Sea through the Humen Gate, locating at the northeast of the PRE with a yearly sediment load of $658 \times 10^{4} \mathrm{t}$ (Dong et al., 2006). The yearly freshwater discharge from the Guangzhou channel is $3.8 \times 10^{10} \mathrm{~m}^{3}$. Suspended sediment in the GZPR is composed mainly of clay and silt with a high percentage of organic particles because of urban sewage (Dong et al., 2006). The average sediment accumulation rate in the GZPR was $1.17 \mathrm{~cm} \mathrm{yr}^{-1}$ (Zhang et al., 2002). The GZPR system is strongly affected by the combination of seasonal monsoon winds, tidal dynamics, complex topography, and large seasonal variations in both the runoff and coastal circulation (Dong et al., 2006). The terrestrial organic $\mathrm{C}$ contribution to the surface sediments in the GZPR is ca. $78 \%$ (He et al., 2010). However, evidence for bacterial contributions to Pearl River OM has been reported, including relatively lower C:N ratios than those in local plants and enriched concentrations of deoxy sugars in the surface sediments (fucose and rhamnose) (He et al., 2010).

\subsection{Sediment sampling and sample processing}

Thirteen sediment samples were collected at the study site in January of 2010. The sampling area and stations are shown in Fig. 1. Topographical characteristics of the sampling stations are summarized in Table 1. Sediment samples were collected using a piston lead core equipped with a PVC tube of inner diameter $6 \mathrm{~cm}$ and $47 \mathrm{~cm}$ long. The length of sediment cores collected was $35 \mathrm{~cm}$. The cores were immediately stored in ice and transported to the laboratory. In the present study, we used the upper $8 \mathrm{~cm}$ of each sediment core, in which sediments were thoroughly mixed, for analyses. 
Table 1. Topographical characteristics of the sampling stations.

\begin{tabular}{|c|c|c|c|c|c|c|c|c|c|c|c|c|c|}
\hline & S1 & S2 & S3 & S4 & S5 & S6 & S7 & S8 & S9 & S10 & S11 & S12 & S13 \\
\hline Latitude $\left({ }^{\circ}\right) \mathrm{N}$ & $23^{\circ} 06^{\prime} 679^{\prime \prime}$ & $23^{\circ} 06^{\prime} 323^{\prime \prime}$ & $23^{\circ} 04^{\prime} 482^{\prime \prime}$ & $23^{\circ} 03^{\prime} 052^{\prime \prime}$ & $23^{\circ} 02^{\prime} 958^{\prime \prime}$ & $23^{\circ} 02^{\prime} 366^{\prime \prime}$ & $23^{\circ} 02^{\prime} 115^{\prime \prime}$ & $23^{\circ} 04^{\prime} 061^{\prime \prime}$ & $23^{\circ} 05^{\prime} 487^{\prime \prime}$ & $23^{\circ} 06^{\prime} 129^{\prime \prime}$ & $23^{\circ} 06^{\prime} 289^{\prime \prime}$ & $23^{\circ} 06^{\prime} 585^{\prime \prime}$ & $23^{\circ} 06^{\prime} 201^{\prime \prime}$ \\
\hline Longitude $\left(^{\circ}\right) \mathrm{E}$ & $113^{\circ} 17^{\prime} 365^{\prime \prime}$ & $113^{\circ} 14^{\prime} 588^{\prime \prime}$ & $113^{\circ} 15^{\prime} 512^{\prime \prime}$ & $113^{\circ} 16^{\prime} 556^{\prime \prime}$ & $113^{\circ} 18^{\prime} 111^{\prime \prime}$ & $113^{\circ} 21^{\prime} 224^{\prime \prime}$ & $113^{\circ} 21^{\prime} 948^{\prime \prime}$ & $113^{\circ} 21^{\prime} 947^{\prime \prime}$ & $113^{\circ} 24^{\prime} 610^{\prime \prime}$ & $113^{\circ} 23^{\prime} 710^{\prime \prime}$ & $113^{\circ} 21^{\prime} 722^{\prime \prime}$ & $113^{\circ} 21^{\prime} 022^{\prime \prime}$ & $113^{\circ} 18^{\prime} 880^{\prime \prime}$ \\
\hline $\mathrm{H}(\mathrm{m})$ & 540 & 540 & 541 & 542 & 542 & 541 & 541 & 541 & 541 & 541 & 541 & 541 & 541 \\
\hline Water depth $(\mathrm{m})$ & 3.8 & 1.9 & 2.6 & 2.2 & 2.4 & 1.8 & 1.0 & 1.7 & 2.7 & 2.4 & 3.4 & 2.7 & 0.5 \\
\hline
\end{tabular}

H, elevation.

Table 2. Average weight percents $(\%)$ of the three sediment fractions at the sampling stations with and without the treatment of freeze-drying and sonication.

\begin{tabular}{|c|c|c|c|c|c|c|c|c|c|c|c|c|c|}
\hline Sediment fraction & S1 & S2 & S3 & S4 & S5 & S6 & S7 & S8 & S9 & S10 & S11 & S12 & S13 \\
\hline \multicolumn{14}{|c|}{ Treatments with freeze-drying and sonication } \\
\hline $\mathrm{CPOM}(\%)$ & $75.9(0.17)$ & $51.1(0.12)$ & $9.96(0.09)$ & $21.6(0.04)$ & $7.28(0.11)$ & $9.12(0.06)$ & $54.1(0.77)$ & $17.6(0.21)$ & $26.1(0.08)$ & $28.3(0.85)$ & $72.8(0.09)$ & $15.9(0.10)$ & $13.3(0.10)$ \\
\hline FPOM $(\%)$ & $23.6(0.12)$ & $48.3(0.09)$ & $87.4(0.04)$ & $72.8(0.06)$ & $85.4(0.05)$ & $87.9(0.08)$ & $44.7(0.10)$ & $79.3(0.69)$ & $71.6(0.12)$ & $64.4(1.01)$ & $24.9(0.66)$ & $70.7(0.09)$ & $78.4(0.09)$ \\
\hline $\operatorname{UDOM}(\%)$ & $0.500(0.03)$ & $0.540(0.01)$ & $2.64(0.08)$ & $5.58(0.11)$ & $7.34(0.11)$ & $2.94(0.07)$ & $1.26(0.08)$ & $3.06(0.10)$ & $2.22(0.09)$ & $7.28(0.04)$ & $2.34(0.10)$ & $13.4(0.12)$ & $8.32(0.12)$ \\
\hline \multicolumn{14}{|c|}{ Treatments without freeze-drying and sonication } \\
\hline $\mathrm{CPOM}(\%)$ & $75.8(0.12)$ & $51.1(0.11)$ & $9.98(0.08)$ & $21.5(0.12)$ & $7.25(0.10)$ & $9.18(0.04)$ & $54.2(0.39)$ & $17.9(0.07)$ & $26.0(0.11)$ & $29.6(0.50)$ & $72.7(0.07)$ & $15.9(0.10)$ & $13.5(0.10)$ \\
\hline FPOM $(\%)$ & $23.7(0.05)$ & $48.4(0.07)$ & $87.3(0.12)$ & $72.9(0.09)$ & $85.3(0.08)$ & $87.8(0.45)$ & $44.5(0.29)$ & $79.2(0.76)$ & $71.6(0.11)$ & $63.3(1.16)$ & $24.9(0.75)$ & $71.3(0.56)$ & $78.3(0.56)$ \\
\hline $\operatorname{UDOM}(\%)$ & $0.490(0.01)$ & $0.520(0.01)$ & $2.69(0.07)$ & $5.67(0.11)$ & $7.42(0.08)$ & $3.05(0.08)$ & $1.37(0.05)$ & $2.95(0.10)$ & $2.36(0.10)$ & $7.13(0.16)$ & $2.49(0.10)$ & $12.8(0.69)$ & $8.22(0.69)$ \\
\hline
\end{tabular}

CPOM, coarse particulate organic matter; FPOM, fine particulate organic matter; UDOM, ultrafiltered dissolved organic matter; standard deviation in the parenthesis.

Samples were freeze-dried, gently homogenized by grinding in an agate mortar, and stored in polyethylene vials prior to analyses.

\subsection{Sediment fractionation}

Sediment samples were dispersed by sonication. Coarse particulate organic matter (CPOM) in the sediment was separated by sieving onto a $63-\mu \mathrm{m}$ Nitex screen and oven-dried at $40^{\circ} \mathrm{C}$. The size of CPOM is $>63 \mu \mathrm{m}$. The sand-free suspension was then passed through a Nalgene filter with a $0.2 \mu \mathrm{m}$ cutoff size, to get fine particulate organic matter (FPOM). The size range of FPOM is between 0.2 and $63 \mu \mathrm{m}$. The FPOM fraction was oven-dried at $40^{\circ} \mathrm{C}$. The ultra-dissolved organic matter (UDOM) fraction that permeated the $0.2 \mu \mathrm{m}$ pore filter was recovered with MSC300 cup type ultra-filter system with a nominal cutoff size of 1000 atomic mass units (Daltons), corresponding roughly to $0.001 \mu \mathrm{m}$. The size range of UDOM is between 0.001 and $0.2 \mu \mathrm{m}$. The UDOM fraction was freeze-dried prior to analysis. The detailed sediment fractionation procedure is shown in Fig. 2. The weight percentages of the individual sediment fractions are shown in Table 2. To investigate the effects of freeze-drying and sonication on the yields of the three size fractions, sediment samples were fractionated according to the above procedure but without the steps of freeze-drying and sonication with three replicates. ANOVA analysis was used to test whether there were significant differences between the yields of the three size fractions with and without the treatment of freezedrying and sonication using the statistical software SPSS (SPSS 16.0).

\subsection{Elemental analysis}

Total organic carbon (TOC) for CPOM and FPOM was determined using the wet oxidation method (Gaudette et al., 1974). About $0.2 \mathrm{~g}$ of CPOM and FPOM (dry weight) was used for TOC determination with a precision of $\pm 0.7 \%$. Concentrations of total organic $\mathrm{C}$ and inorganic $\mathrm{C}$ for UDOM were measured with the high-temperature catalytic oxidation method using a Shimadzu TOC-V CPH TOC analyzer with precisions of $\pm 0.9 \%$ and $\pm 0.8 \%$, respectively. About $20 \mathrm{~mL}$ of UDOM was used for total organic $\mathrm{C}$ and inorganic $\mathrm{C}$ analyses. Total $\mathrm{N}$ for CPOM and FPOM was determined using Kjeldahl digestion with a precision of $\pm 0.8 \%$ (Morgan et al., 1957). About $0.2 \mathrm{~g}$ of CPOM and FPOM was used for total $\mathrm{N}$ analysis. Total $\mathrm{N}$ for UDOM was determined using Persulfate digestion with a precision of $\pm 0.6 \%$ (D'Elia et al., 1977). About $20 \mathrm{~mL}$ of UDOM was used in determination of total N.

\subsection{Amino acid analysis}

Approximately $500 \mathrm{mg}$ of dried CPOM or FPOM particles and 5 to $10 \mathrm{mg}$ of UDOM powder were hydrolyzed with $6 \mathrm{M} \mathrm{HCl}$ at $110^{\circ} \mathrm{C}$ for $24 \mathrm{~h}$ in a sealed screw capped glass vial (Labco Exetainer, UK) under $\mathrm{N}_{2}$. The hydrolysate was filtered to remove mineral particles (Whatman GF/F), then the $\mathrm{pH}$ of the solution was adjusted with $\mathrm{KOH}$ to a range of 6.6 to 6.8 . Thereafter, the hydrolysate was centrifuged and filtered before the chromatography analysis (Whatman GF/F). Derivatization with OPA and Nisobutyryl-L-cysteine (IBLC) was performed in a borate 


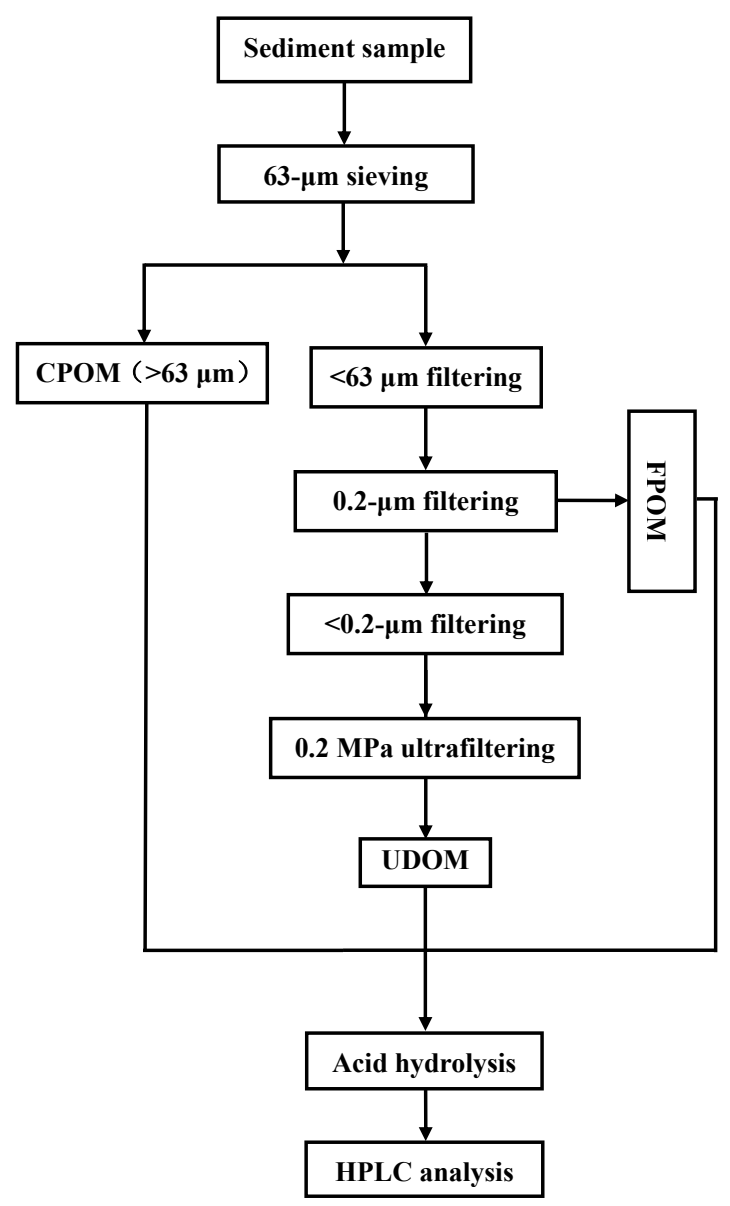

Fig. 2. Schematic graph for sediment fractionation procedure, in which CPOM is for coarse particulate organic matter, FPOM for fine particulate organic matter, and UDOM for ultrafiltered dissolved organic matter.

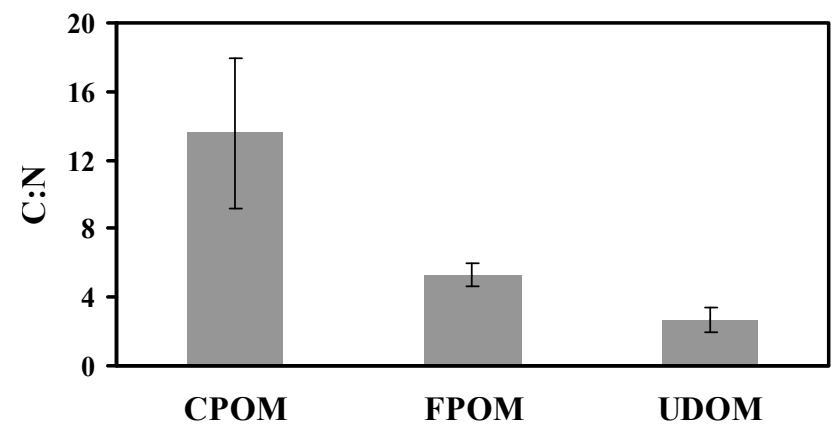

Fig. 3. Spatial-averaged mole $\mathrm{C}: \mathrm{N}$ ratios for the coarse particulate organic matter (CPOM), fine particulate organic matter (FPOM), and ultra-filtered dissolved organic matter (UDOM) size fractions based on values at the 13 sampling stations. Bars represent standard deviations.

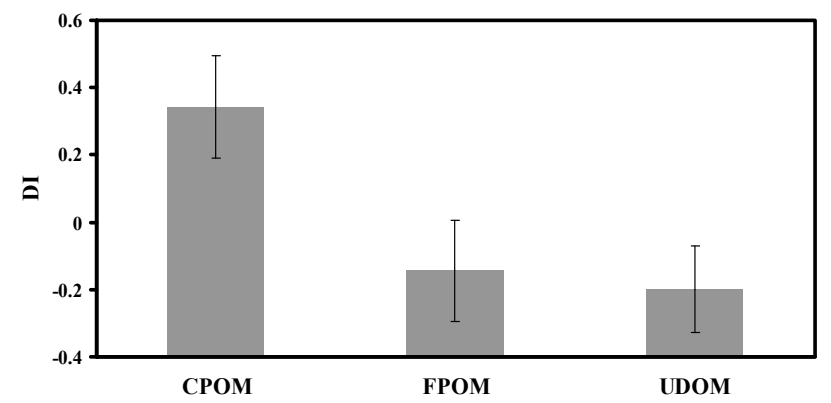

Fig. 4. Diagenetic index (DI) for the coarse particulate (CPOM), fine particulate (FPOM), and ultrafiltered dissolved organic matter (UDOM) size fractions. Bars represent standard deviations.

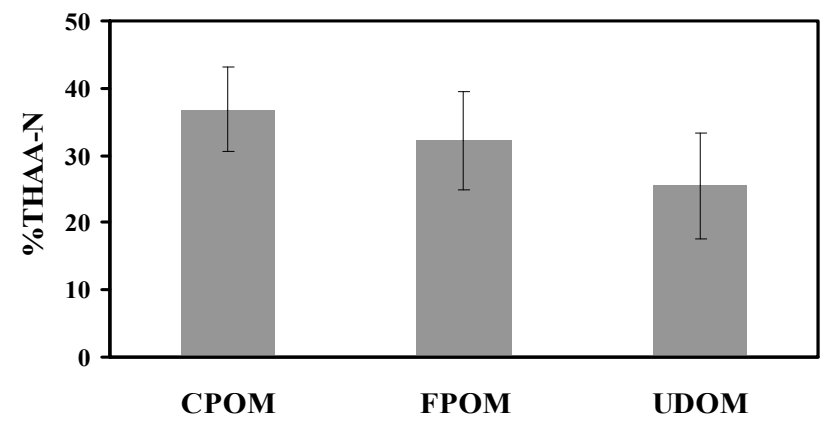

Fig. 5. Spatial-averaged percentages of total nitrogen $(\mathrm{N})$ as total hydrolysable amino acids (THAA) for the coarse particulate organic matter (CPOM), fine particulate organic matter (FPOM), and ultrafiltered dissolved organic matter (UDOM) size fractions based on values at the 13 sampling stations. Bars represent standard deviations.

buffer (pH 9.5) (Kaiser and Benner, 2005). Separation and detection of D-enantiomers were performed on an Agilent 1100 system with a Agilent Zorbax Eclipse XDB-C18 reverse phase column $(150 \mathrm{~mm} \times 4.6 \mathrm{~mm}, 5 \mu \mathrm{m})$ and a guard column $(4 \times 4 \mathrm{~mm}, 5 \mathrm{~mL})$. The flow rate was $0.8 \mathrm{~mL} \mathrm{~min}^{-1}$ and the elution temperature was $20^{\circ} \mathrm{C}$. A mobile phase linear gradient was applied, from $100 \% 23 \mathrm{mmol} \mathrm{L}^{-1}$ Sodium Acetate (pH 5.95-6.0) to 53.5\% methanol/acetonitrile (600:50 $\mathrm{v} / \mathrm{v})$ after $75 \mathrm{~min}$ and $80 \%$ methanol/acetonitrile $(600: 50 \mathrm{v} / \mathrm{v})$ after $85 \mathrm{~min}$. The excitation wavelength was set at $230 \mathrm{~nm}$ (band width $25 \mathrm{~nm}$ ). The emission length was set at $445 \mathrm{~nm}$ (cutoff filter $280 \mathrm{~nm}$ and band width $50 \mathrm{~nm}$ ). DAA was quantified using four external DAA standard solutions containing a mix of D-serine (D-Ser), D-glutamic acid (D-Glu), Dalanine (D-Ala), and D-aspartic acid (D-Asp). The DAA measurements were corrected for chemical racemization occurring during hydrolysis. The correction was based on the average of measured racemization rates of free and protein amino acids (Kaiser and Benner, 2005). Percentages of D-enantiomers produced during acid hydrolysis of Lenantiomers for Asp, Glu, Ser, and Ala were 4.4\%, $2.0 \%$, 

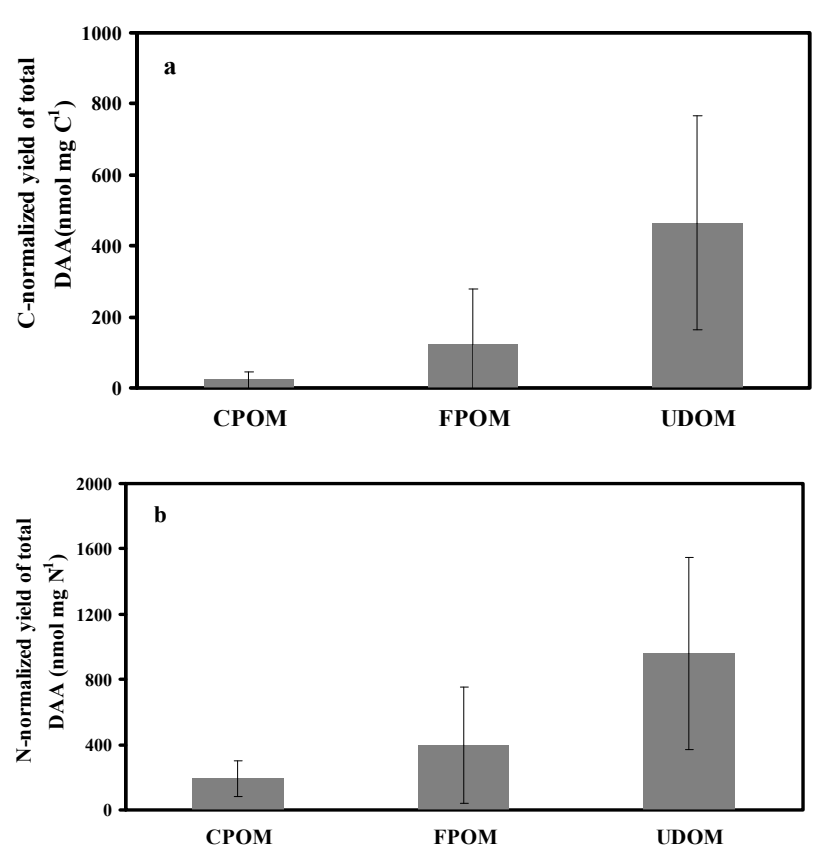

Fig. 6. Spatial-averaged C-(a) and N-(b) normalized yields of total D-amino acids (total DAA, the sum of D-Ala, D-Glu, D-Asp and $\mathrm{D}$-Ser) in the coarse particulate organic matter (CPOM), fine particulate organic matter (FPOM), and ultra-filtered dissolved organic matter (UDOM) size fractions based on values at the 13 sampling stations. Bars represent standard deviations.

$0.3 \%$, and $1.2 \%$, respectively (Kaiser and Benner, 2005). The DAA concentrations were reported after reducing the D-enantiomers produced during acid hydrolysis. The concentration of THAA pools was analyzed by an ICS 3000 Dionex AAA-Direct System with an AminoPac PA10 analytical column $(2 \mathrm{~mm} \times 250 \mathrm{~mm}, 8.5 \mu \mathrm{m})$ with guard column $(2 \mathrm{~mm} \times 50 \mathrm{~mm})$ and IPAD detector. The flow rate was $0.25 \mathrm{~mL} \mathrm{~min}^{-1}$ and the elution temperature was $30^{\circ} \mathrm{C}$. Concentrations of the individual amino acids were calculated according to individual standard curves, produced from a mixture of the amino standard solution AA-S-18 (SigmaAldrich), to which ornithine (Orn), $\beta$-Ala, $\gamma$-Aba, and $\alpha$-Aba were added. Twenty one amino acids were analyzed and the sum of them was used to represent the THAA concentration. In our study no corrections for the acid-hydrolysis efficiency were conducted (Benner and Kaiser, 2003).

\section{Results}

\subsection{Bulk characteristics for CPOM, FPOM, and UDOM}

The topographical characteristics of the sampling stations are shown in Table 1. Results of the yields of the three fractions with and without the treatment of freeze-drying and
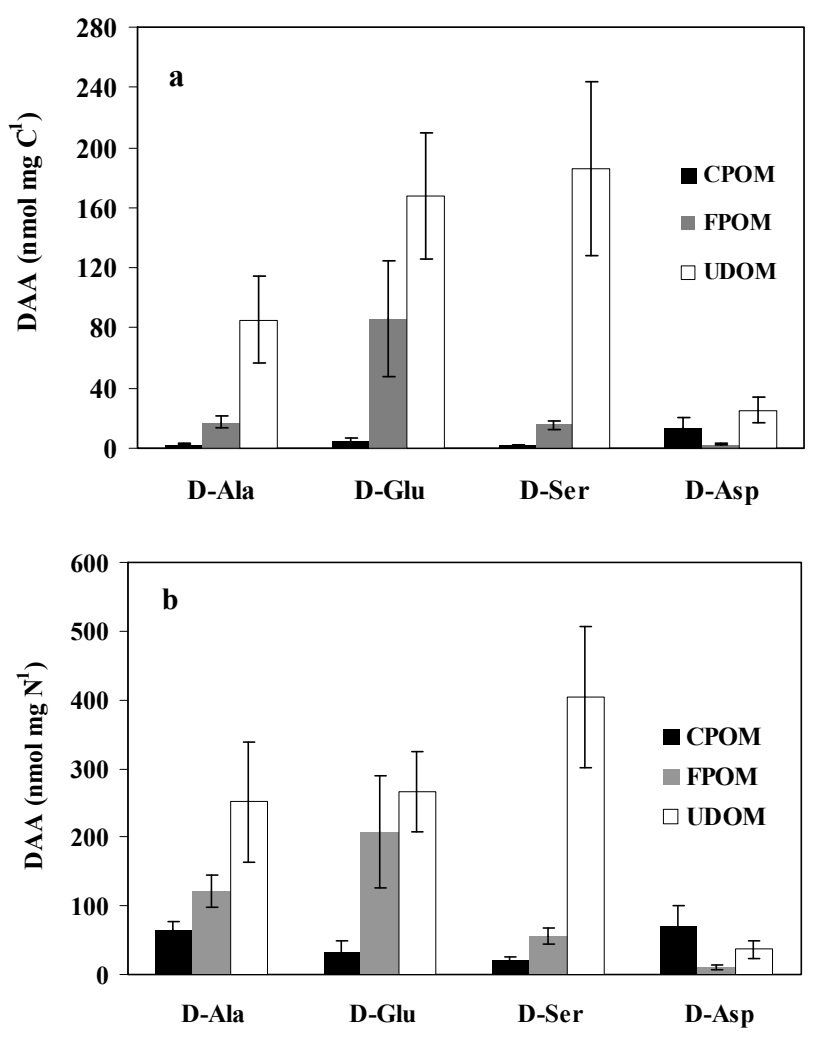

Fig. 7. Spatial-averaged C-(a) and N-(b) normalized yields of individual D-amino acids (DAAs), including D-Ala (D-alanine), D-Glu (D-glutamic acid), D-Asp (D-aspartic acid), and D-Ser (D-serine) in the coarse particulate organic matter (CPOM), fine particulate organic matter (FPOM) and ultra-filtered dissolved organic matter (UDOM) size fractions. Bars represent standard deviations.

sonication are listed in Table 2. ANOVA analysis showed that there were no significant differences between the yields of the three size fractions with and without the treatment of freeze-drying and sonication $(P<0.05)$, indicating that the effects of freeze-drying and sonication on the yields of the fractions were negligible.

Sediment TOC content increased with the sediment size. Average TOC contents for UDOM, FPOM, and CPOM were $4.12,8.95$, and $11.0 \mathrm{mg} \mathrm{Cg}^{-1}$ dry weight, respectively. The largest average total $\mathrm{N}$ content was observed in the FPOM fraction (2.1 $\mathrm{mg} \mathrm{Ng}^{-1}$ dry weight) and CPOM had the lowest average total $\mathrm{N}$ content $\left(1.1 \mathrm{mg} \mathrm{N} \mathrm{g}^{-1}\right.$ dry weight). The UDOM fraction had an intermediate total $\mathrm{N}$ value of $1.9 \mathrm{mg} \mathrm{N} \mathrm{g}^{-1}$ dry weight. The results indicated that CPOM was relatively enriched in organic $\mathrm{C}$ and depleted in $\mathrm{N}$ compared to the FPOM and UDOM fractions, whereas FPOM was enriched in $\mathrm{N}$-containing molecules. $\mathrm{C}: \mathrm{N}$ ratios varied greatly from 1.2 to 41 among the fractions of the samples (Table 3). For each sampling location, the highest $\mathrm{C}: \mathrm{N}$ ratio value was in CPOM among the three fractions, whereas the lowest C:N ratio was in UDOM except for S6 and S7 
Table 3. Total organic carbon (TOC) and total nitrogen (Total N) contents, C:N ratios (mole TOC:Total N), percentages of TOC and total N as total hydrolysable amino acids (THAA) in sediment samples of different size fractions.

\begin{tabular}{|c|c|c|c|c|c|c|}
\hline Sampling station & Size fraction & TOC (wt \%) & Total N (wt \%) & $\mathrm{C}: \mathrm{N}$ & $\% \mathrm{C}$ as THAA & $\% \mathrm{~N}$ as THAA \\
\hline \multirow[t]{3}{*}{$\mathrm{S} 1$} & CPOM & 0.25 & 0.017 & 17.2 & 2.91 & 47.57 \\
\hline & FPOM & 0.73 & 0.185 & 4.6 & 57.13 & 34.75 \\
\hline & UDOM & 1.41 & 0.620 & 2.7 & 10.45 & 12.82 \\
\hline \multirow[t]{3}{*}{$\mathrm{S} 2$} & СРOM & 2.21 & 0.063 & 40.9 & 8.18 & 50.46 \\
\hline & FPOM & 1.00 & 0.144 & 8.1 & 4.04 & 31.15 \\
\hline & UDOM & 1.15 & 0.450 & 3.0 & 6.19 & 14.29 \\
\hline \multirow[t]{3}{*}{ S3 } & CPOM & 2.55 & 0.254 & 11.7 & 21.83 & 37.89 \\
\hline & FPOM & 1.09 & 0.290 & 4.4 & 3.72 & 15.73 \\
\hline & UDOM & 0.39 & 0.300 & 1.5 & 27.53 & 29.46 \\
\hline \multirow[t]{3}{*}{ S4 } & CPOM & 0.59 & 0.067 & 10.3 & 7.49 & 36.27 \\
\hline & FPOM & 0.80 & 0.129 & 7.2 & 23.24 & 49.90 \\
\hline & UDOM & 0.30 & 0.090 & 3.9 & 15.75 & 21.83 \\
\hline \multirow[t]{3}{*}{ S5 } & СРОМ & 1.53 & 0.109 & 16.4 & 17.14 & 46.08 \\
\hline & FPOM & 0.72 & 0.172 & 4.9 & 14.87 & 51.91 \\
\hline & UDOM & 0.11 & 0.070 & 1.8 & 24.76 & 29.82 \\
\hline \multirow[t]{3}{*}{ S6 } & СРОМ & 0.46 & 0.047 & 11.4 & 6.58 & 30.74 \\
\hline & FPOM & 0.43 & 0.134 & 3.7 & 27.20 & 46.12 \\
\hline & UDOM & 0.29 & 0.060 & 5.6 & 18.44 & 58.30 \\
\hline \multirow[t]{3}{*}{ S7 } & СРOM & 0.37 & 0.038 & 11.4 & 2.21 & 20.09 \\
\hline & FPOM & 0.60 & 0.136 & 5.1 & 38.29 & 56.65 \\
\hline & UDOM & 0.46 & 0.100 & 5.4 & 11.88 & 49.47 \\
\hline \multirow[t]{3}{*}{ S8 } & СРОМ & 1.13 & 0.163 & 8.1 & 21.67 & 50.60 \\
\hline & FPOM & 0.88 & 0.195 & 5.3 & 4.23 & 14.67 \\
\hline & UDOM & 0.35 & 0.150 & 2.7 & 14.23 & 30.20 \\
\hline \multirow[t]{3}{*}{ S9 } & СРОМ & 0.55 & 0.050 & 12.8 & 2.26 & 20.30 \\
\hline & FPOM & 0.95 & 0.230 & 4.8 & 26.06 & 30.43 \\
\hline & UDOM & 0.46 & 0.340 & 1.6 & 28.46 & 35.16 \\
\hline \multirow[t]{3}{*}{$\mathrm{S} 10$} & CPOM & 0.98 & 0.113 & 10.1 & 19.01 & 57.34 \\
\hline & FPOM & 0.79 & 0.207 & 4.5 & 12.52 & 28.94 \\
\hline & UDOM & 0.08 & 0.040 & 2.3 & 14.93 & 21.09 \\
\hline \multirow[t]{3}{*}{ S11 } & СРОМ & 0.38 & 0.041 & 10.8 & 2.43 & 22.39 \\
\hline & FPOM & 1.10 & 0.184 & 7.0 & 14.62 & 14.62 \\
\hline & UDOM & 0.16 & 0.140 & 1.3 & 30.44 & 13.96 \\
\hline \multirow[t]{3}{*}{$\mathrm{S} 12$} & СРОМ & 0.79 & 0.174 & 5.3 & 9.18 & 28.51 \\
\hline & FPOM & 1.31 & 0.370 & 4.1 & 18.87 & 19.28 \\
\hline & UDOM & 0.10 & 0.050 & 2.3 & 7.31 & 13.78 \\
\hline \multirow[t]{3}{*}{ S13 } & СРOM & 2.44 & 0.274 & 10.4 & 15.56 & 31.08 \\
\hline & FPOM & 1.24 & 0.291 & 5.0 & 5.69 & 24.41 \\
\hline & UDOM & 0.10 & 0.100 & 1.2 & 17.97 & 1.36 \\
\hline
\end{tabular}

CPOM, coarse particulate organic matter; FPOM, fine particulate organic matter; UDOM, ultrafiltered dissolved organic matter.

(Table 3). The $\mathrm{C}: \mathrm{N}$ ratio range in $\mathrm{CPOM}$ was relatively wide (5.3-41), whereas the $\mathrm{C}: \mathrm{N}$ ratio ranges in FPOM and UDOM were relatively narrower (3.7-8.1 and $1.2-5.6$, respectively) (Table 3 ). The highest average $\mathrm{C}: \mathrm{N}$ value was found in CPOM, whereas UDOM had the lowest average $\mathrm{C}: \mathrm{N}$ ratios (Fig. 3), also indicating that the CPOM fraction was $\mathrm{N}$ poor relative to the FPOM and UDOM fractions.

\subsection{Amino acid yields and compositions}

The THAA compositions within each size fraction and sampling station were relatively depleted in acidic amino acids (Asp and Glu) (Table 4). $\beta$-Ala, $\gamma$-Aba, and $\alpha$-Aba were depleted, while Lys and Arg were relatively enriched in the three size fractions (Table 4). The degradation index generally decreased with decreasing sediment fraction sizes (Dauwe et al., 1999) (Fig. 4). The percentages of total $\mathrm{N}$ as THAA were from $20 \%$ to $57 \%$ in CPOM, from $15 \%$ to $57 \%$ in FPOM, and from $1.36 \%$ to $58 \%$ in UDOM. The percentages of total $\mathrm{N}$ as THAA generally overlapped over a broad range, exhibiting a relatively large variability among the sediment samples (Table 3 ). The average percentages of total $\mathrm{N}$ as THAA were $37 \%, 32 \%$, and $26 \%$ in CPOM, FPOM, and UDOM, respectively (Fig. 5).

$\mathrm{C}$ - and $\mathrm{N}$-normalized yields of specific and total Denantiomers (D-Ala, D-Glu, D-Asp and D-Ser) varied among 
Table 4. Mole percents (\%) of 21 amino acids in sediment samples of different size fractions.

\begin{tabular}{|c|c|c|c|c|c|c|c|c|c|c|c|c|c|c|c|c|c|c|c|c|c|c|}
\hline $\begin{array}{l}\text { Sampling } \\
\text { station }\end{array}$ & Size fraction & Asp & Thr & Ser & Glu & Gly & Ala & Val & Cys & Met & Ile & Leu & Tyr & Phe & $\begin{array}{l}\beta- \\
\text { Ala }\end{array}$ & $\begin{array}{l}\alpha- \\
\mathrm{ABA}\end{array}$ & $\begin{array}{l}\gamma- \\
\mathrm{ABA}\end{array}$ & Orn & Lys & His & $\operatorname{Arg}$ & Pro \\
\hline \multirow{3}{*}{ S2 } & CPOM & 1.33 & 0.00 & 0.00 & 0.00 & 0.00 & 0.00 & 1.74 & 1.12 & 0.97 & 0.00 & 2.90 & 3.17 & 5.94 & 0.00 & 0.00 & 3.46 & 5.80 & 40.78 & 0.82 & 31.98 & 0.00 \\
\hline & FPOM & 0.00 & 0.00 & 0.00 & 0.00 & 0.94 & 0.19 & 0.16 & 2.93 & 0.00 & 0.00 & 8.70 & 0.96 & 9.16 & 8.57 & 0.00 & 0.00 & 3.59 & 30.46 & 0.20 & 34.15 & 0.00 \\
\hline & UDOM & 0.21 & 0.01 & 0.00 & 0.00 & 0.04 & 0.00 & 0.39 & 4.51 & 0.04 & 0.00 & 11.23 & 0.73 & 8.35 & 2.47 & 0.00 & 0.00 & 2.35 & 25.60 & 0.51 & 39.54 & 4.02 \\
\hline \multirow{3}{*}{ S3 } & СРОМ & 0.00 & 0.20 & 0.32 & 0.16 & 1.52 & 1.73 & 3.27 & 0.00 & 2.14 & 7.64 & 17.98 & 4.52 & 12.84 & 2.03 & 0.00 & 1.98 & 2.68 & 24.13 & 1.88 & 14.98 & 0.00 \\
\hline & FPOM & 00 & 0.00 & 0.12 & 1.62 & 0.10 & 0.00 & 0.00 & 3.15 & 8.66 & 0.00 & 0.00 & 0.00 & 13.56 & 0.00 & 0.00 & 0.00 & 4.16 & 0.00 & 0.11 & 62.75 & 5.77 \\
\hline & UDOM & 0.02 & 0.00 & 0.03 & 3.65 & 0.00 & 0.74 & 0.54 & 3.28 & 10.34 & 0.00 & 0.00 & 0.00 & 14.67 & 0.03 & 0.00 & 0.00 & 5.46 & 5.65 & 0.95 & 52.26 & 2.38 \\
\hline \multirow{3}{*}{ S4 } & СРОМ & 1.76 & 6.48 & 7.44 & 6.20 & 16.92 & 13.86 & 6.75 & 0.00 & 0.40 & 3.70 & 8.35 & 1.99 & 3.90 & 0.83 & 0.00 & 0.88 & 0.60 & 4.77 & 0.16 & 2.73 & 12.27 \\
\hline & FPOM & 0.00 & 14.58 & 1.78 & 2.74 & 11.09 & 5.47 & 5.65 & 0.00 & 1.31 & 6.66 & 15.67 & 3.15 & 8.62 & 2.09 & 0.00 & 1.31 & 1.09 & 11.34 & 0.64 & 6.81 & 0.00 \\
\hline & UDOM & 0.31 & 16.78 & 3.57 & 0.99 & 9.48 & 1.26 & 4.61 & 0.00 & 2.66 & 6.84 & 17.59 & 4.23 & 1.20 & 3.14 & 0.00 & 1.84 & 1.97 & 13.67 & 1.54 & 7.46 & 0.86 \\
\hline \multirow{3}{*}{ S5 } & CPOM & 0.49 & 6.16 & 7.80 & 7.87 & 20.04 & 14.43 & 8.69 & 0.00 & 0.19 & 4.73 & 9.69 & 1.97 & 4.92 & 1.36 & 0.00 & 0.69 & 0.72 & 6.01 & 0.32 & 3.93 & 0.00 \\
\hline & FPOM & 0.00 & 0.44 & 0.13 & 0.00 & 0.11 & 0.00 & 0.25 & 1.00 & 3.17 & 0.00 & 0.00 & 1.30 & 5.19 & 0.00 & 0.00 & 0.00 & 5.71 & 12.92 & 0.48 & 68.16 & 1.14 \\
\hline & UDOM & 1.21 & 0.24 & 6.53 & 0.00 & 0.68 & 0.04 & 0.03 & 2.08 & 3.99 & 0.00 & 0.00 & 1.05 & 5.84 & 0.00 & 0.00 & 0.00 & 6.88 & 14.61 & 0.64 & 50.16 & 6.02 \\
\hline \multirow{3}{*}{ S6 } & CPOM & 3.83 & 5.87 & 12.66 & 5.25 & 21.93 & 22.62 & 6.16 & 0.14 & 0.00 & 3.32 & 4.89 & 0.50 & 2.07 & 0.00 & 0.00 & 0.00 & 0.00 & 2.58 & 1.45 & 1.56 & 5.16 \\
\hline & FPOM & 0.27 & 6.59 & 8.37 & 1.44 & 15.19 & 10.74 & 9.03 & 0.11 & 1.93 & 5.32 & 6.89 & 0.97 & 3.51 & 2.24 & 0.08 & 3.27 & 6.53 & 5.90 & 0.44 & 2.82 & 8.36 \\
\hline & UDOM & 0.36 & 7.53 & 5.92 & 1.03 & 6.42 & 6.44 & 10.25 & 0.09 & 3.66 & 8.46 & 8.98 & 1.27 & 1.97 & 3.16 & 0.00 & 3.58 & 7.82 & 8.19 & 0.32 & 5.94 & 8.61 \\
\hline \multirow{3}{*}{ S7 } & СРOM & 0.13 & 0.00 & 0.10 & 0.11 & 0.16 & 0.00 & 0.30 & 0.09 & 0.00 & 0.00 & 0.00 & 4.59 & 7.36 & 1.56 & 0.05 & 2.27 & 4.54 & 36.5 & 2.42 & 34.62 & 5.13 \\
\hline & FPOM & 00 & 0.47 & 0.00 & 1.32 & 0.47 & 0.00 & 1.06 & 0.62 & 0.66 & 0.32 & 2.03 & 4.92 & 10.87 & 0.00 & 0.00 & 0.68 & 3.19 & 26.63 & 2.47 & 44.29 & 0.00 \\
\hline & UDOM & 0.05 & 0.69 & 0.09 & 1.78 & 0.83 & 0.00 & 1.63 & 0.89 & 1.37 & 0.06 & 3.64 & 4.98 & 11.23 & 0.00 & 0.08 & 0.28 & 1.29 & 21.37 & 2.59 & 46.31 & 0.84 \\
\hline \multirow{3}{*}{ S8 } & CPOM & 1.20 & 8.12 & 8.71 & 3.63 & 19.85 & 16.20 & 8.04 & 0.25 & 0.26 & 4.57 & 7.34 & 0.25 & 3.23 & 1.32 & 0.89 & 0.00 & 0.39 & 4.30 & 0.76 & 1.83 & 8.85 \\
\hline & FPOM & 12 & 6.59 & 98 & 0.00 & 21.14 & 16.06 & 9.27 & 0.17 & 1.23 & 5.29 & 6.91 & 0.74 & 3.32 & 0.00 & 0.00 & 0.00 & 0.00 & 6.14 & 0.37 & 3.14 & 10.53 \\
\hline & UDOM & 0.06 & 0.63 & 9.49 & 0.00 & 21.67 & 15.27 & 11.33 & 0.11 & 1.35 & 6.33 & 5.62 & 1.15 & 3.11 & 0.00 & 0.00 & 0.00 & 0.00 & 7.61 & 10.56 & 5.42 & 0.29 \\
\hline \multirow{3}{*}{ S9 } & СРОМ & 0.73 & 8.15 & 9.31 & 2.60 & 19.49 & 16.91 & 8.04 & 0.00 & 0.22 & 4.60 & 7.73 & 0.21 & 3.17 & 0.00 & 0.00 & 0.00 & 0.00 & 5.57 & 0.91 & 2.97 & 9.38 \\
\hline & FPOM & 42 & 5.69 & 12.14 & 4.91 & 18.36 & 13.42 & 7.04 & 0.16 & 0.27 & 4.09 & 5.91 & 1.16 & 3.17 & 2.43 & 0.06 & 2.17 & 4.26 & 3.34 & 0.26 & 1.92 & 6.82 \\
\hline & UDOM & 0.04 & 14.05 & 16.18 & 2.31 & 4.79 & 8.55 & 6.37 & 0.14 & 0.29 & 3.78 & 3.37 & 0.83 & 3.49 & 2.14 & 0.00 & 2.59 & 2.57 & 1.59 & 0.16 & 24.13 & 2.63 \\
\hline \multirow{3}{*}{ S10 } & СРОМ & 1.09 & 0.00 & 4.60 & 1.03 & 0.00 & 2.1 & 2.7 & 0.00 & 0.0 & 11.99 & 4.74 & 8.03 & 7.1 & 0.0 & 0.00 & 0.0 & 39.91 & 13.3 & 0.0 & 3.2 & 0.00 \\
\hline & FPOM & 0.09 & 0.33 & 0.14 & 0.00 & 0.18 & 0.12 & 0.20 & 0.99 & 0.00 & 0.00 & 3.34 & 0.44 & 3.94 & 5.26 & 0.00 & 0.00 & 4.67 & 30.63 & 0.35 & 48.47 & 0.86 \\
\hline & UDOM & 2.11 & 0.84 & 0.06 & 0.00 & 0.36 & 0.33 & 0.01 & 1.57 & 0.00 & 0.00 & 2.33 & 0.18 & 1.16 & 6.38 & 0.00 & 0.00 & 2.95 & 31.68 & 0.57 & 45.11 & 4.36 \\
\hline \multirow{3}{*}{ S11 } & СРОМ & 0.35 & 6.99 & 8.52 & 1.79 & 20.1 & 15.73 & 9.2 & 0.39 & 1.6 & 5.6 & 7.77 & 0.41 & 3.1 & 0.0 & 0.00 & 0.00 & 0.0 & 6.2 & 0.7 & 2.40 & 8.89 \\
\hline & FPOM & 1.68 & 3.51 & 9.61 & 2.51 & 12.24 & 10.01 & 5.31 & 0.95 & 0.00 & 2.56 & 4.25 & 1.49 & 2.62 & 16.23 & 0.00 & 0.00 & 14.43 & 2.14 & 0.74 & 0.97 & 8.75 \\
\hline & UDOM & 3.58 & 1.36 & 10.88 & 2.64 & 5.25 & 7.46 & 3.29 & 2.61 & 0.00 & 0.68 & 1.12 & 1.96 & 0.85 & 14.23 & 0.04 & 0.00 & 8.62 & 1.92 & 0.84 & 20.94 & 11.73 \\
\hline \multirow{3}{*}{$\mathrm{S} 12$} & СРОМ & 0.23 & 0.00 & 0.00 & 0.38 & 0.24 & 0.00 & 0.94 & 0.00 & 0.32 & 1.17 & & 4.17 & 5.92 & 1.42 & 0.00 & 0.98 & 4.34 & 32.00 & 4.00 & 41.81 & 0.00 \\
\hline & FPOM & 0.07 & 0.12 & 0.12 & 0.33 & 0.09 & 0.00 & 0.12 & 0.00 & 0.13 & 0.00 & 0.00 & 4.68 & 7.02 & 2.78 & 0.07 & 2.48 & 4.87 & 39.66 & 2.89 & 30.13 & 4.44 \\
\hline & UDOM & 0.18 & 0.94 & 0.22 & 0.00 & 0.02 & 0.00 & 0.28 & 0.00 & 0.06 & 0.00 & 0.00 & 6.35 & 9.02 & 3.79 & 0.00 & 2.67 & 4.99 & 40.01 & 1.53 & 29.49 & 0.45 \\
\hline \multirow{3}{*}{ S13 } & CPOM & 1.32 & 6.77 & 7.65 & 4.00 & 18.66 & 15.70 & 9.64 & 0.00 & 0.44 & 6.10 & 9.66 & 0.97 & 4.80 & 0 & 0.0 & 0.00 & 0.00 & 6.39 & 0.1 & 2.90 & 4.91 \\
\hline & FPOM & 1.18 & 7.81 & 7.98 & 3.36 & 18.68 & 15.41 & 8.01 & 0.20 & 0.18 & 4.48 & 7.65 & 0.13 & 2.82 & 1.63 & 0.00 & 1.73 & 1.18 & 5.20 & 0.60 & 2.96 & 8.79 \\
\hline & UDOM & 1.05 & 8.76 & 9.05 & 3.98 & 19.30 & 16.42 & 4.75 & 0.03 & 0.01 & 2.09 & 6.19 & 0.01 & 0.06 & 2.19 & 0.07 & 0.04 & 0.73 & 3.67 & 12.26 & 8.91 & 0.43 \\
\hline
\end{tabular}

CPOM, coarse particulate organic matter; FPOM, fine particulate organic matter; UDOM, ultrafiltered dissolved organic matter.

the three fractions (Table 5). The highest average C- and $\mathrm{N}$-normalized yields of total DAA were found in UDOM, whereas the lowest ones in CPOM (Fig. 6a, b).

Both the spatially averaged $\mathrm{C}$ - and $\mathrm{N}$-normalized yields of D-Ala, D-Glu, D-Ser increased with the sediment OM sizes (Fig. 7a, b). In contrast, the highest average C-normalized yield of D-Asp was found in UDOM and the lowest in CPOM, whereas the highest average $\mathrm{N}$-normalized yield of D-Asp was found in CPOM and the lowest in UDOM (Fig. 7a, b)

\section{Discussion}

\subsection{Diagenetic trends for sediment OM of different size classes}

Bacteria are important agents for sediment OM degradation. As microbial decomposition progresses, the reactive components of sediment OM are selectively consumed, leading to an enrichment of less reactive sediment OM components (Wakeham et al., 1997). N-containing bio-molecules exhibit different dynamics during sediment OM diagenesis, thus these N-containing molecules can be used as good indicators of OM "freshness" and diagenetic state (Lomstein et al., 2006; Keil et al., 2000; Vandewiele et al., 2009). Specifically, amino acids and the respective D-enantiomers have been reported to display different reactivities at different stages of OM diagenesis (Dauwe and Middelburg, 1998; Lomstein et al., 2006; Vandewiele et al., 2009). Distribution patterns observed with amino acids and their D-isomers can be employed for the assessment of their relative reactivity. In the present study, compositional features that seemed sensitive to different stages of diagenesis were amino acid based diagenetic index (DI) (Dauwe and Middelburg, 1998), C:N ratio, percentage of total $\mathrm{N}$ as THAA, $\mathrm{C}$-and $\mathrm{N}$-normalized yields of total DAA, and $\mathrm{C}$ - and $\mathrm{N}$-normalized yields of $\mathrm{D}$ Ala, D-Glu, D-Ser.

In the present study, the DI values generally decreased from the larger to smaller sizes of OM, and the DI for CPOM was significant higher than those for FPOM and UDOM (Fig. 4). The DI is a reliable and robust index for the extent of diagenetic alteration in sediments (Dauwe and Middelburg, 1998; Keil et al., 2000; Lomstein et al., 2006; Vandewiele et al., 2009). Our study showed that the DI could be used 
Table 5. C- and N-normalized yields of individual (D-Ala, D-Glu, D-Asp and D-Ser) and total D-amino acids (total DAA, the sum of D-Ala, D-Glu, D-Asp and D-Ser) in sediment samples of different size fractions.

\begin{tabular}{|c|c|c|c|c|c|c|c|c|c|c|c|}
\hline \multirow[t]{2}{*}{$\begin{array}{l}\text { Sampling } \\
\text { station }\end{array}$} & \multirow[t]{2}{*}{$\begin{array}{l}\text { Size } \\
\text { fraction }\end{array}$} & D-Ala & D-Glu & D-Asp & D-Ser & D-Ala & D-Glu & D-Asp & D-Ser & Total DAA & Total DAA \\
\hline & & \multicolumn{4}{|c|}{$\mathrm{nmol} \mathrm{mg} \mathrm{C}-1$} & \multicolumn{4}{|c|}{$\mathrm{nmol} \mathrm{mg} \mathrm{N}^{-1}$} & $\mathrm{nmol} \mathrm{mg} \mathrm{C}-1$ & $\mathrm{nmol} \mathrm{mgN}^{-1}$ \\
\hline S1 & $\begin{array}{l}\text { CPOM } \\
\text { FPOM } \\
\text { UDOM }\end{array}$ & 2.61 & & & & 225 & & & & 2.61 & 225 \\
\hline S2 & $\begin{array}{l}\text { CPOM } \\
\text { FPOM } \\
\text { UDOM }\end{array}$ & $\begin{array}{l}7.11 \\
70.7\end{array}$ & 4.44 & & & $\begin{array}{l}227 \\
362\end{array}$ & 68.2 & & & $\begin{array}{l}7.11 \\
4.44 \\
70.7\end{array}$ & $\begin{array}{l}227 \\
68.2 \\
362\end{array}$ \\
\hline S3 & $\begin{array}{l}\text { CPOM } \\
\text { FPOM } \\
\text { UDOM }\end{array}$ & 11.6 & 130 & 49.4 & $\begin{array}{l}13.9 \\
1481\end{array}$ & 203 & 167 & 63.4 & $\begin{array}{l}122 \\
1903\end{array}$ & $\begin{array}{l}25.4 \\
1660\end{array}$ & $\begin{array}{l}325 \\
2134\end{array}$ \\
\hline S4 & $\begin{array}{l}\text { CPOM } \\
\text { FPOM } \\
\text { UDOM }\end{array}$ & & 40.4 & & $\begin{array}{l}10.2 \\
441\end{array}$ & & 184 & & $\begin{array}{l}122 \\
1446\end{array}$ & $\begin{array}{l}10.2 \\
40.4 \\
441\end{array}$ & $\begin{array}{l}122 \\
184 \\
1446\end{array}$ \\
\hline S5 & $\begin{array}{l}\text { CPOM } \\
\text { FPOM } \\
\text { UDOM }\end{array}$ & $\begin{array}{l}8.78 \\
25.8 \\
708\end{array}$ & $\begin{array}{l}18.5 \\
378\end{array}$ & $\begin{array}{l}4.83 \\
207\end{array}$ & & $\begin{array}{l}117 \\
461 \\
2243\end{array}$ & $\begin{array}{l}165 \\
599\end{array}$ & $\begin{array}{l}43.1 \\
328\end{array}$ & & $\begin{array}{l}8.78 \\
49.1 \\
1294\end{array}$ & $\begin{array}{l}117 \\
669 \\
3170\end{array}$ \\
\hline S6 & $\begin{array}{l}\text { CPOM } \\
\text { FPOM } \\
\text { UDOM }\end{array}$ & 9.98 & 243 & 22.4 & $\begin{array}{l}8.74 \\
13.8 \\
355\end{array}$ & 68.2 & 1176 & 76.6 & $\begin{array}{l}80.7 \\
47.3 \\
1719\end{array}$ & $\begin{array}{l}8.74 \\
46.2 \\
598\end{array}$ & $\begin{array}{l}80.7 \\
192 \\
2894\end{array}$ \\
\hline S7 & $\begin{array}{l}\text { CPOM } \\
\text { FPOM } \\
\text { UDOM }\end{array}$ & & 13.7 & 2.18 & 9.28 & & 37.5 & 5.99 & 25.5 & 25.1 & 69.0 \\
\hline S8 & $\begin{array}{l}\text { CPOM } \\
\text { FPOM } \\
\text { UDOM }\end{array}$ & $\begin{array}{l}1.55 \\
8.53\end{array}$ & & & & $\begin{array}{l}16.7 \\
99.2\end{array}$ & & & & $\begin{array}{l}1.55 \\
8.53\end{array}$ & $\begin{array}{l}16.7 \\
99.2\end{array}$ \\
\hline S9 & $\begin{array}{l}\text { CPOM } \\
\text { FPOM } \\
\text { UDOM }\end{array}$ & $\begin{array}{l}3.15 \\
44.7\end{array}$ & 63.2 & & $\begin{array}{l}2.25 \\
29.0 \\
136\end{array}$ & $\begin{array}{l}120 \\
214\end{array}$ & 85.9 & & $\begin{array}{l}42.7 \\
69.4 \\
185\end{array}$ & $\begin{array}{l}5.40 \\
73.7 \\
199\end{array}$ & $\begin{array}{l}162 \\
283 \\
271\end{array}$ \\
\hline $\mathrm{S} 10$ & $\begin{array}{l}\text { CPOM } \\
\text { FPOM } \\
\text { UDOM }\end{array}$ & 8.91 & 9.89 & 4.06 & $\begin{array}{l}3.56 \\
65.8\end{array}$ & 125 & 46.6 & 19.1 & $\begin{array}{l}25.0 \\
310\end{array}$ & $\begin{array}{l}12.5 \\
79.8\end{array}$ & $\begin{array}{l}150 \\
376\end{array}$ \\
\hline S11 & $\begin{array}{l}\text { CPOM } \\
\text { FPOM } \\
\text { UDOM }\end{array}$ & $\begin{array}{l}0.49 \\
21.4\end{array}$ & $\begin{array}{l}23.5 \\
284\end{array}$ & $\begin{array}{l}2.41 \\
73.1\end{array}$ & 25.1 & $\begin{array}{l}26.3 \\
88.0\end{array}$ & $\begin{array}{l}48.4 \\
322\end{array}$ & $\begin{array}{l}64.6 \\
82.8\end{array}$ & 51.7 & $\begin{array}{l}2.90 \\
70.0 \\
357\end{array}$ & $\begin{array}{l}90.9 \\
188 \\
404\end{array}$ \\
\hline $\mathrm{S} 12$ & $\begin{array}{l}\text { CPOM } \\
\text { FPOM } \\
\text { UDOM }\end{array}$ & 104 & $\begin{array}{l}57.3 \\
1009\end{array}$ & 15.0 & 43.6 & 445 & $\begin{array}{l}431 \\
2151\end{array}$ & 112 & 92.9 & $\begin{array}{l}72.3 \\
1157\end{array}$ & $\begin{array}{l}543 \\
2689\end{array}$ \\
\hline S13 & $\begin{array}{l}\text { CPOM } \\
\text { FPOM } \\
\text { UDOM }\end{array}$ & 328 & 1084 & 165 & & 670 & 1107 & 747 & & $\begin{array}{l}165 \\
1412\end{array}$ & $\begin{array}{l}747 \\
1777\end{array}$ \\
\hline
\end{tabular}

CPOM, sediment coarse particulate organic matter; FPOM, fine particulate organic matter; UDOM, ultra-filtered dissolved organic matter; D-Ala, D-alanine; D-Glu, D-glutamic acid; D-Asp, D-aspartic acid; D-Ser, D-serine; the blank, below detection limit.

to characterizing the diagenetic state of sediment particulate and dissolved OM. The C:N ratio was also found to consistently decrease with declining particle size, demonstrating that the bulk parameters could be used to indicate the diagenetic states of sediment particulate and dissolved parameter. CPOM was enriched in terrestrial organic $\mathrm{C}$ and depleted in $\mathrm{N}$. The lowest $\mathrm{C}: \mathrm{N}$ ratio in UDOM suggested that $\mathrm{C}$-rich $\mathrm{OM}$ was degraded and some low molecular weight $\mathrm{OM}$ rich in $\mathrm{N}$ was produced as microbial degradation progressed. The consistent trend of the DI and C:N ratio with the OM sizes showed that the bulk elemental parameter could also be used to indicate the diagenetic history of OM.

The percentages of total $\mathrm{N}$ as THAA decreasing with the sediment particle sizes indicates that amino acids are relatively more reactive than TOC or bulk $\mathrm{N}$ in the sediments. The percentages of total $\mathrm{N}$ as THAA are diagenetically sen- sitive and have generally been observed to fall with progressive degradation, for example with depths in marine sediment cores (e.g., Henrichs et al., 1987; Lomstein et al., 2006; Keil et al., 2000; Pedersen et al., 2001). Cowie and Hedges (1992) found a decrease of the percentage of total $\mathrm{N}$ as THAA with the sediment depth and demonstrated the potential of this parameter as a valuable diagenetic indicator. It has been reported that percentages of total $\mathrm{N}$ as THAA for most living organisms and tree leaves are $>50 \%$ but decrease as degradation progresses to near $10 \%$ for ancient sediments (Cowie and Hedges, 1994). Although diagenetic alterations of amino acids are variable, observations on the general trend toward low percentages of total $\mathrm{N}$ as THAA with declining particle sizes support the feasibility of the parameters as a diagenetic indicator. 
The observed C- and N-normalized yields of total DAA trends were in the order of CPOM $<$ FPOM $<$ UDOM, which agreed with the observed patterns of degradation alteration in the sediment samples, with CPOM being the least processed and UDOM the most. Therefore, CPOM was the most reactive with the largest size, and UDOM was the least reactive with the smallest size among the three size fractions in our study. Similarly, the percentage of total dissolved organic $\mathrm{C}$ as total DAA has been shown to increase during the decomposition of fresh, algal-derived DOM from an Arctic ice floe (Amon et al., 2001). Moreover, Tremblay and Benner (2009) found that \% DAA (the ratio of summed mole of DAA to THAA) increased with OM in the Amazon River system. These studies indicate that $\mathrm{C}$ - and $\mathrm{N}$-normalized yields of total DAA are useful diagenetic indicators. C- and $\mathrm{N}$-normalized yields of individual D-enantiomers other than those of D-Asp show consistent diagenetic trends towards the decreasing physical size of OM, suggesting the selective preservation of the three DAAs other than D-Asp. The absence of the trend for D-Asp suggested a different diagenetic pathway of D-Asp in our study area. A possible reason to explain the discrepancy in the patterns of the four D-enantiomers is that other bacterial macromolecules with reactivity different from petidoglycan may have contributed to D-Asp (Kaiser and Benner, 2008). Nevertheless, the size-specific trends in our study showed the potential of individual D-enantiomers yields to be used as diagenetic indicators. The relatively higher D-Ser in UDOM suggested that D-Ser was much more preserved than other D-enantiomers as the diagenesis of sediment OM progressed. The high concentration of D-Ser in UDOM might be attributed to the variability in biopolymer structures and in the microbial community compositions in the sediments.

\subsection{The "size-reactivity continuum" model for sediment $\mathrm{OM}$}

The "size-reactivity continuum" model has been used to relate bioavailability to size and diagenetic state of OM for dissolved OM in various water environments (Amon and Benner, 1996; Tremblay and Benner, 2009). Generally, diagenetically young OM seems to be most bio-reactive. OM becomes less reactive and smaller in physical size as biodegradation proceeds. The "size-reactivity continuum" model indicates that the major pathway of $\mathrm{OM}$ decomposition is a continuous change from bio-reactive organic particles and macromolecules to small refractory organic molecules (Amon and Benner, 1996).

Our incubation study on sediment CPOM and FPOM showed that the bio-reactivity of CPOM was significantly higher than that of FPOM $(P<0.05)$. The diagenetic pathway of larger POM in sediments is towards smaller POM and subsequent dissolved OM. Our study showed that the "sizereactivity continuum" model was applicable to sediment particulate and dissolved OM.

\section{Concluding remarks}

Distributions of amino acids and their D-isomers among the sediment fractions indicated that the amino acid-based diagenetic index, C:N ratio, and percentage of total $\mathrm{N}$ represented by total hydrolysable amino acids could be used as diagenetic indicators. Furthermore, the diagenetic state of sediment $\mathrm{OM}$ could also be characterized by the $\mathrm{C}$ - and $\mathrm{N}$ normalized yields of total D-amino acids, and C- and $\mathrm{N}$ normalized yields of D-alanine, D-glutamic acid, D-serine. The "size-reactivity continuum" model developed for the water column was supported by our results of the bio-reactivity of sediment particulate OM of varying size fractions. Our study showed that the "size-reactivity continuum" model was applicable to sediment particulate and dissolved OM.

Acknowledgements. This work was partly supported by grants from the Chinese National Natural Science Foundation (Nos. 51039007 and 51179212) and the Fundamental Research Funds for the Central Universities.

Edited by: J. Middelburg

\section{References}

Amon, R. M. W. and Benner, R.: Bacterial utilization of different size classes of dissolved organic matter, Limnol. Oceanogr., 41, 41-51, 1996.

Amon, R. M. W., Fitznar, H., and Benner, R.: Linkages among the bioreactivity, chemical composition, and diagenetic state of marine dissolved organic matter, Limnol. Oceanogr., 46, 287297, 2001.

Benner, R. and Kaiser, K.: Abundance of amino sugars and peptidoglycan in marine particulate and dissolved organic matter, Limnol. Oceanogr., 48, 118-128, 2003.

Cowie, G. L. and Hedges, J. I.: Sources and reactivities of amino acids in a coastal marine environment, Limnol. Oceanogr., 37 , 703-724, 1992.

Cowie, G. L. and Hedges, J. I.: Biochemical indicators of diagenetic alteration in natural organic matter mixtures, Nature, 369, 304307, 1994.

Dauwe, B. and Middelburg, J. J.: Amino acids and hexosamines as indicators of organic matter degradation state in North Sea sediments, Limnol. Oceanogr., 43, 782-798, 1998.

Dauwe, B., Middelburg, J. J., Herman, P. M. J., and Heip, C. H. R.: Linking diagenetic alteration of amino acids and bulk organic matter reactivity, Limnol. Oceanogr., 44, 1809-1814, 1999.

Davis, J., Kaiser, K., and Benner, R.: Amino acid and amino sugar yields and compositions as indicators of dissolved organic matter diagenesis, Org. Geochem., 40, 343-352, 2009.

D'Elia, C. F., Steudler, P. A., and Corwin, N.: Determination of total nitrogen in aqueous samples using persulfate digestion, Limnol. Oceanogr., 22, 760-764, 1977.

Dong, L., Su, J., Li, Y., Xia, X., and Guan, W.: Physical processes and sediment dynamics in the Pearl River, in: The Environment in Asia Pacific Harbours, edited by: Wolanski, E., Springer, Germany, 127-137, 2006. 
Gaudette, H. E., Flight, W. R., Toner, L., and Folger, D. W.: An inexpensive titration method for the determination of organic carbon in recent sediments, J. Sediment. Res., 44, 249-253, 1974.

Harrison, P. J., Yin, K., Lee, J. H. W., Gan, J., and Liu, H.: Physicalbiological coupling in the Pearl River Estuary, Cont. Shelf Res., 28, 1405-1415, 2008.

He, B., Dai, M., Huang, W., Liu, Q., Chen, H., and Xu, L.: Sources and accumulation of organic carbon in the Pearl River Estuary surface sediment as indicated by elemental, stable carbon isotopic, and carbohydrate compositions, Biogeosciences, 7, 3343 3362, doi:10.5194/bg-7-3343-2010, 2010.

Hedges, J., Mayorga, E., Tsamakis, E., McClain, M., Aufdenkampe, A., Quay, P., Richey, J., Benner, R., Opsahl, S., and Black, B.: Organic matter in Bolivian tributaries of the Amazon River: A comparison to the lower mainstream, Limnol. Oceanogr., 45, 1449-1466, 2000.

Henrichs, S. M. and Farrington, J. W.: Early diagenesis of amino acids and organic matter in two coastal marine sediments, Geochim. Cosmochim. Ac., 51, 1-15, 1987.

Jørgensen, N. O. G. and Middelboe, M.: Occurrence and bacterial cycling of $\mathrm{D}$ amino acid isomers in an estuarine environment, Biogeochemistry, 81, 77-94, 2006.

Kaiser, K. and Benner, R.: Hydrolysis-induced racemization of amino acids, Limnol. Oceanogr-Meth., 3, 318-325, 2005.

Kaiser, K. and Benner, R.: Major bacterial contribution to the ocean reservoir of detrital organic carbon and nitrogen, Limnol. Oceanogr., 53, 99-112, 2008.

Keil, R. G., Tsamakis, E., and Hedges, J. I.: Early diagenesis of particulate amino acis in marine systems, in: Perspectives in amino acid and protein geochemistry, edited by: Goodfriend, G. A., Collins, M. J., Fogel, M. L., Macko, S. A., and Wehmiller, J. F., Oxford University Press, 69-82, 2000.

Lomstein, B. A., Jørgensen, B. B., Schubert, C. J., and Niggemann, J.: Amino acid biogeo-and stereochemistry in coastal Chilean sediments, Geochim. Cosmochim. Ac., 70, 2970-2989, 2006.
Lomstein, B. A., Niggemann, J., Jørgensen, B. B., and Langerhuus, A. T.: Accumulation of prokaryotic remains during organic matter diagenesis in surface sediments off Peru, Limnol. Oceanogr., 54, 1139-1151, 2009.

Morgan, G. B., Lackey, J. B., and Gilcreas, F. W.: Quantitative determination of organic nitrogen in water, sewage, and industrial wastes, Anal. Chem., 29, 833-835, 1957.

Nagata, T. and Kirchman, D. L.: Bacterial mortality: A pathway for the formation of refractory DOM? In: Microbial Biosystems: New Frontiers: Proceedings of the 8th International Symposium on Microbial Ecology, Halifax, Canada, 9-14 August 1998, 153158, 2000.

Pedersen, A. U., Thomsen, T. R., Lomstein, B. A., and Jørgensen, N. O. G.: Bacterial influence on amino acid enantiomerization in a coastal marine sediment, Limnol. Oceanogr., 46, 1358-1369, 2001.

Riemann, L. and Middelboe, M.: Stability of bacterial and viral community compositions in Danish coastal waters as depicted by DNA fingerprinting techniques, Aquat. Microb. Ecol., 27, 219232, 2002.

Tremblay, L. and Benner, R.: Organic matter diagenesis and bacterial contributions to detrital carbon and nitrogen in the Amazon River system, Limnol. Oceanogr., 54, 681-691, 2009.

Vandewiele, S., Cowie, G., Soetaert, K., and Middelburg, J. J.: Amino acid biogeochemistry and organic matter degradation state across the Pakistan margin oxygen minimum zone, DeepSea Res. Pt. II, 56, 318-334, 2009.

Wakeham, S. G., Lee, C., Hedges, J. I., Hernes, P. J., and Peterson, M. L.: Molecular indicators of diagenetic status in marine organic matter, Geochim. Cosmochim. Ac., 61, 5363-5369, 1997.

Yin, K. and Harrison, P. J.: Nitrogen over enrichment in subtropical Pearl River estuarine coastal waters: Possible causes and consequences, Cont. Shelf Res., 28, 1435-1442, 2008.

Zhang, G., Parker, A., House, A., Mai, B., Li, X., Kang, Y., and Wang, Z.: Sedimentary records of DDT and $\mathrm{HCH}$ in the Pearl River Delta, South China, Environ. Sci. Technol., 36, 36713677, 2002. 